\title{
STRATEGIC RESPONSES OF BUSINESS TO CONSUMERISM
}

Howard L. Alford, Morgan State University

\begin{abstract}
Through the private enterprise system of fierce competition and heightened entrepreneurship, providers of consumer goods have frequently intensified their efforts to maximize profits. In doing this, the interest and needs of workers and the consuming public were somewhat ignored, which resulted in what some felt to be questionable practices on the part of private enterprise. The public became interested in pricing, ads, quality and durability of goods together with the overall fidelity of business. Business considered strategic alternatives in responding to the concerns of society. Strategic responses to consumerism by the business community included a broad continuum of measures designed to allay these judgements. This paper addressed four issues including: education and information, marketing, customer service, and consumer affairs departments. It was recognized that the public raised ethical conduct questions regarding advertising and pricing long before consumerism reached its peak during the decade of the 1960's.
\end{abstract}

\section{Introduction}

Americans enjoy the fruits of businesses' commercial and industrial activities. Employing an especially unique brand of business structure, the private enterprise system, one which encourages competition and entrepreneurship, the American people have become a nation of consumers. The development of economic goods for consumption has truly escalated throughout this nation over the course of the last one hundred years. This condition was ushered onto the current economic setting with industrial revolution and the rise of the factory system. Over the years, the business sector experienced heightened rivalry as a result of intensive economic development. Manufacturers of consumer goods placed much emphasis on production and frequently the interest and needs of workers and the consuming public were ignored.

As consumer goods and services increasingly became available, several efforts were expanded by business, government and the general society to insure that these providers exercised good ethical conduct. Various segments of the public became keenly concerned with truth in advertising, pricing, quality and durability of goods to- gether with the overall fidelity of business. Increasingly, businesses were attacked and criticized for what some felt to be questionable practices. With active participants and expanded numbers contesting alleged practices, an era emerged which became known as the consumer movement or Consumerism.

The purpose of this paper is to discuss briefly the strategic responses of the business community to consumerism. Four responses were addressed which comprise the following: education, marketing, customer service, and consumer affairs.

\section{Education and Information}

Consumer advocates claim that the balance of power lies with the "seller" and that business has failed to exercise its massive power in a responsible manner. During the 1960's the consumer movement came into full bloom and the American consuming public became aware of the importance of shopping wisely. However, the first great expansion of consumerism began during the 1930 's. 
Among the first to recognize the big consumer movement of the 1930's was Marshall Mott, of the Hartford, Connecticut Better Business Bureau, who was cognizant of the enormity of this movement and expressed confidence that the business community would respond in a positive manner. To be sure, the BBB is one significant response to consumer interest in business and sponsored one of the earliest successful educational consumer institutes at Indianapolis, Indiana in 1940. For ten weeks, local consumers attended lectures by experts from big businesses who spoke on the basic facts of buying and selling. Within one year Muriel Tsvetkoff, of the San Francisco $\mathrm{BBB}$, suggested that consumers would continue to trust local BBB's to provide information regarding questionable business activity.(1)

In Arlington, Virginia, C. Victor Werne then of the Virginia BBB wrote an article entitled "Bureau Management" in 1940 and published by the $\mathrm{BBB}$. Mr. Werne assumed the position that if consumerism proceeded throughout the corridors of education and information, it could reap great benefits to both business, and society. During this early period the association of BBB's sponsored several consumer conferences which brought together representatives from business, education, government, and the public in a precursor of events designed to educate, inform and build confidence in business.(2) Cognizant of the social economic conditions in the U.S. at the close of World War II, the United Business Service, a weekly forecast service, alerted the public by sending out warning signals in various parts of the country, using the slogan, "Before you invest, investigate."(3)

The council of BBB's employs its division of Broadcast, Public Affairs and Information to inform and educate the consumer. Using telephones, newspapers, broadcasts, books, booklets and television the division maintains one of the nation's largest and most effective consumer education programs. By the early 1970's the $\mathrm{BBB}$ added a service which provides advice on contributions. The Philanthropic Advisory Service encourages truth and honesty among charitable organizations that solicit from business and the general public.

Surveys reveal that some banks subscribe to negativism about consumerism and that these banks do not understand the full strength of its course. However, despite of these attitudes, banks of all sizes have begun to recognize the advantages of hiring consumer affairs specialist who are helpful in developing information and community liaison programs.(4) Several additional responses were made during the 1960's. Credit World published an article in 1978 entitled "Consumer Business Trades" which emphasized efforts of the banking system to use credit cards more efficiently as an education and information service to consumers. A new customer pamphlet explaining credit rights in housing was made available by the banks and VISA announced reduced service fees.(5)

During the same year the National Pharmaceutical Council invited six professionals active in consumer affairs to meet with executives of large pharmaceutical companies to discuss issues related to consumerism and possible drug abuse.(6)

By April 1987, 1,000 video stores in Boston, Los Angeles, and New York were carrying videocassettes called Free Vees. These are commercials of five to 30 minutes long and several advertisers including Chrysler and Ford will offer these commercial videocassettes on loan for free. David Heneberry of Video Information Network says that the tapes are for consumers who want additional information about products they are considering buying.(7) The response of business by informing and educating the consumer has represented a rather broad spectrum. Some reflexes were promulgated through legislative assemblage as in the "Pure Food and Drug Act." However, businesses are continuing to face the challenge to keep America an enlightened consumer.

\section{Marketing}

The marketing component as a business response to consumerism developed much earlier than others when we consider advertising. Acknowledged in 1914 by the BBB, "Truth in Advertising", was a forerunner to the movement. A senate committee headed by the former president Harry S. Truman in 1941 recognized the key role the $\mathrm{BBB}$ was playing as an effective selfregulatory agency in the advertising industry.

Some years later the advertising industry cooperated with the BBB in developing and publishing "Declaration of Responsibilities for Impr- 
oving Public Confidence in Advertising." This effort was supported by agencies, media, and the BBB. In 1964 the Advertising Federation of America and the BBB jointly adapted, "The Advertising Code of American Business."(8)

With the support of businesses, the BBB initiated and supported advertising and business practices as exemplified by the National Automobile Dealer Standards with the National Automobile Dealers Association, furniture ad standards with the National Retail Furniture Association, and other programs with Commercial banks, Savings banks, and Federal Savings and Loan Associations. In 1953, President Eisenhower sent a message to the BBB stating that he was aware of the thousands of business firms and millions of American citizens who benefit from the efforts of the BBB.(9)

One study involving pricing concepts was conducted to determine the extent of informational imperfections for seventeen representative products in Syracuse, New York. It indicated that for products with relatively small actual price dispersions, consumer's perceptions were accurate. These products were two foods (milk and eggs) and heating oil. It was suggested that consumers under-shopped in areas where the price reflected broad dispersions, and that consumers were inaccurate in their perception of price dispersions.(10)

Marketing-oriented businesses coordinate employee efforts from the chief executive officer on down to the new hire. Decisions are shown to be more of a team effort. Marketing-oriented corporations are deemed to be the best competitors in the modern business world. These businesses are concerned about quality competitive marketing practices.(11)

This author believes that advertising professional services is a direct response to consumerism, particularly as they relate to doctors and 1awyers. When the Supreme Court ruled in 1977 that the Arizona Bar Association could not stop lawyers from advertising their services, the way was opened to all professional services.

In Philadelphia, as a result of local ads on television, one dental clinic was able to increase its staff by five additional dentists. The clinic advertised lower prices compared to the cost of other dentists.(12) Retail store dentistry including Sears Roebuck and Montgomery Ward are entering the business. One dental professional observing this activity remarked, "I think we're seeing a sign of the times. Professionals are having to become businessmen and to market their products to consumer groups."(13) Lawyers have also joined the rush as one Chicago lawyer declared, "In another 10 years advertising will be the way most people find a lawyer."(14)

During the AT\&T sponsored Marketing Applications Symposium held at the end of May 1986 in New York City, tele-marketing and its five primary application areas (order processing, customer service, sales support, accounting, and promotional management) were discussed by representatives from AT\&T, General Foods, Tel-Excel, Allstate Insurance, and ComMark International. Since 1976, revenues attributable to tele-marketing efforts have increased 16-fold to $\$ 100$ billion per year as of 1986.(15)

In 1955, the Direct Marketing Association (DMA) issued its first code of ethics for direct marketers; since that time, the DMA has implemented two selfregulatory programs: the Mail Preference Service in 1971 and the Telephone Preference Service in 1985. The DMA has since sponsored several conferences with the U.S. Office of Consumer Affairs focusing on the ethical practices of direct marketers.(16)

\section{CUSTOMER SERVICE}

Consumer electronics giant Thomas-Brandt implemented a distribution system which it believes has not only saved the company considerable expense, but also has improved greatly its customer service component. This was done by subcontracting and streamlining its total operations. Managing information with electronic mail was recognized by Suzanne Label in a recent article as being a very useful tool for increasing customer service. Businesses use word processors, voice mail, computer-based message systems and facsimile technology which permits information to be transmitted without retyping, filing, or copying and the data are continuously attainable to users. This system also provide hands on assistance for customer service.(17)

In the article "Chiefs in Beggars Clothing", Melvin Marks cites Charles Lubin, founder and 
former Chief executive of Sara Lee as being an example of management by walking around providing advice to managers with regard to their own practices and procedure, educating and developing managers, and evaluating manager behavior following profits, and a solid style for promoting good management practices in customer relations and services.(18)

An additional response to consumerism involves the practice of several businesses who use form interview or other means for identifying customer needs. These businesses are concerned about balancing the cost of added services with increasing the quality of customer services rendered.(19)

The Briggs and Stratton Corporation has instituted three picking methods that work together to fill routine, scheduled orders but work separately for rush orders. These systems allow Briggs and Stratton to provide fast service and maintain excellent customer service.(20)

The Burroughs Corporation felt the market saturation for main-frame computers before other largecomputer makers. The company contributed this action to poor customer service. Burroughs was forced to recognize fundamental changes in the information processing business before its competitors. McRae is a family-owned business with over $\$ 160$ million in 1984 sales. Chief Executive Officer Richard McRae cites customer service and market research as the prime reasons for success and implies that good marketing strategy and the interest of the consumer helps promote profits.(21)

Corporations who compete in a service area with very similar products as in the case in the financial services industry, have witnessed customer loyalty as the key to success. Responding to consumerism, methods for building customers loyalty were discussed by various financial service industry representatives at the 1986 Financial Marketing Conference, sponsored by the American Marketing Association.(22)

Employee training and management development at Walt Disney World has been recognized as an example of how excellent customer service training can provide a competitive edge.(23) Customer service is increasingly more important to the success of most businesses.

\section{CONSUMER AFFAIRS}

Here again, the Council of Better Business Bureaus recorded early efforts (1930's and 1940 's) by the Indianapolis BBB and the governor of that state and others to establish offices of consumer affairs. While these two initial efforts failed, such offices were established later and interest in continued development of this component of consumerism has sustained. Private enterprise established these offices in hopes of assisting management in recruiting and retaining valid information regarding what consumers want and expect in return for purchased goods and services.

Possibly the most visible consumer affairs professional in the industry is Meredith M. Fernstrom, senior vice-president for public responsibility at American Express Co. The duties of her office include: consulting on company advertising, overseeing the collection of consumer complaints for forwarding to management, control, choice, and personal service. Under her guidance American Express recently helped fund a kit for retired persons on financial planning. (24)

Northern California Grocers Association's (NCGA) consumer affairs advisor, Cheri Harris, works to bring consumers and grocers to a better understanding through teach-ins at member food stores, pubic service announcements, and other methods that will promote mutual respect and an open exchange of information. Ms. Harris proceeded to organize NCGA's first department of consumer affairs and launched an intensive campaign and educational program aimed at bringing the ideas and positions of both factions into sharper focus.(25)

Consumer affairs departments of offices are often headed by a vice president or other senior staff as reported by Davis and Frederick. As a part of Central Management such offices handle consumer inquiries and complaints about a company's product or service. Some companies have installed consumer 'hot lines' for dissatisfied customers to place telephone calls directly to the manufacturer. Davis and Frederick also feel that experienced companies know that these departments can satisfy complaints more quickly, at lower cost, and with less risk of losing goodwill than when legal action is taken and complaints 
receive widespread media publicity.(26)

Consumer affairs professionals frequently must reconcile the commercial goals of their companies with the social goals of consumers they represent, and must maintain a balance. Social marketing can be an effective tool for accomplishing this goal. The Aluminum Association has initiated a statewide campaign in Delaware by utilizing the principles of social marketing to "sell" consumers on the idea of recycling aluminum cans. The cornerstone of the campaign is the toll free hot line consumers can telephone to locate the nearest recycling convenient and save both time and energy.(27)

By the early 1970's the National Association of Mutual Savings Banks (NAMSB) had formed a special committee on Consumer Affairs to study legislation. The association was interested in exploring policies that would be beneficial to consumers.(28) Banks have since developed and advanced the electronic funds transfer system as one method of improving consumer affairs.

The number of U.S. corporations having consumer affairs department is continually rising. Although some companies had such departments many years, the concept is a relatively new one for others. Consumer affairs departments today are taking on additional duties, which include the following: advertising monitoring, product design input, consumer satisfaction research for existing products, warranty and guarantee development, product safety, packaging and labeling, supplier selection, and quality controls.(29)

Corporate consumer affairs departments are under increased scrutiny from senior management to assess the future and direction of their function. A recent study has revealed that management does not really understand the consumer affairs function; thus, consumer affairs professionals must sell themselves more effectively. Within the firm, the consumer affairs professional must fight an assortment of roadblocks, such as the bottom line and the image of being an "outsider on the inside." Problems are a result of the way the function was created and has evolved. However, consumer affairs offices are projected to continue as an active component of the business sector.

\section{CONCLUSION}

The trend toward private-sector solutions to problems seems to be more broadly used during the 1980's. Strategic responses discussed in this paper suggest that the public must be more convinced that it is in their best interest to deal first with consumer affairs professionals rather that government, the media, or the courts. Consumer confidence in business is the key to economic recovery. A recent survey on consumerism in the 1980's reveals that the public believes that during the past ten years, labeling and information about products and services has improved and products are safer.(30)

Consumerism will continue to have a significant effect on business, albeit less dramatic, in the years ahead. Consumerism is not disappearing, it has simply been moving through the stages and running its course. The results of several national opinion polls show that the public still appreciated the benefits of consumerism.(31) The foregoing responses suggest solid avenues which can be explored to allay some criticisms of business.

There are a wide variety of predictions for consumerism and the response of private enterprise in the future. This forecast mirrors a quieter but active consumer movement for the next decade, as business continues to consider alternative strategies in responding to the challenge of consumerism.

Research for this article was made possible with a grant from the Morgan State University Committee on Faculty Research and the Morgan State University Press. 


\section{FOOTNOTES}

1. Wansely, B. Charles. History and Traditions, Oakland, California, The Council of Better Business Bureaus, Inc., 1983, p.12

2. op.cit., p. 13.

3. op.cit., p. 16.

4. Waits, Marilyn K., "Banks and Consumerism: Progress", United States Banker V91 (March 1980): 40-42.

5. "Consumer Business Trends", Credit World, V66 (April 1978): 20-21.

6. Barnes, Nora Ganim, "The Pharamaceutical Industry's Experiment With a Consumer's Advisory Panel: An Inside View", Health Care Management Review, V9 (Fall 1984): 7-10

7. "News and Trends", Fortune Magazine, April 13, 1987, p. 10.

8. Wansley, op.cit., p. 6

9. Wansley, op.cit., p. 20

10. Maynes, E. Scott and Assum, Jerje. "Internationally Imperfect Consumer Markets: Empirical Findings and Policy Implications," Journal of Consumer Affairs, V. 16 (Summer 1982): 26-27.

11. Robinson, Robert A. "Customers Front and Center," Training and Development Journal, V. 16 (Summer 1982): 85-87.

12. Davis, Keith and Frederick, William C., Business and Society New York: McGraw-Hill Book Company, 1984, p. 293.

13. "Moving the Dentist's Chair to Retail Stores," Business Week, January 19, 1981, p. 58.

14. "Ads Start to Take Hold in the Professions", Business Week, July 24, 1978, pp. 122, 124.

15. "Wise Tele-marketing Produces Sales, Committed Customers," Direct Marketing, V49 (July 1986): 80.

16. Tuefel, Robert. "The Good in Working for the Public Good." Direct Marketing, V49 (July 1986) 110.

17. Kissler, Suzanne Pierce. "Managing Information with Electronic Mail," Management Accounting (USA), V67 (April 1986): 16-17.

18. Annandale, Stephen. "The Four Faces of Management," Personnel Management, V34 (July 1986): 4.

19. "Services Marketers Must Balance Customer Satisfaction Against Their Operational Needs." Marketing News, V20 (October 1986$): 2$.

20. "How We Handle Rush Orders as Easily As Routine Picks," Modern Materials Handling V37 (March 1982): 52-54.

21. McRae, Richard. "McRae Assesses the Economy: Northpark, Future Plans," Mississippi Business Journal (August 1985 ): 5.

22. Reiling, Lynn G. "Customer Loyalty Prime Factor in Financial Services," Marketing News, V20 (April 1986): 8-9.

23. Zemke, Ron. "Training Employees to Meet the Public," Training: The Magazine of Human Resources Development, (August 1986$): 41$.

24. Marshall, Jeffrey. "When the Public's Mind Affects the Bottom Line," Credit World, V74 (January/February 1986): 35-36.

25. Johnson, Stanley F. "Improve Your Consumer Affairs Program by Hiring A Consumer Advocate," Association Management, V40 (February 1984): 27.

26. Davis, op.cit., p. 300

27. Rose, Merrill. "Striking a Balance Between Company Goals and Consumer Demands," Public Relations Journal, V40 (Feb. 1984$): 27$.

28. "NAMSB Forms Consumer Affairs Committee," United States Banking, V89 (January 1978): 16-17.

29. Johnson, op.cit., p. 119.

30. Abbott, Howard. "How to Manage Liability," Management Today, (UK) (July 1983): 50-53.

31. Bloom, Paul M. and Greyser, Stephen A. "The Maturing of Consumerism." Harvard Business Review, V59 (November/December 198-

1): $37-39$.

\section{Continued From Page 11}

\section{References}

1. Berliner, Harold I., and Silage, Richard G. "The White Collar Computer," Management Focus, 30:3, 1983, May-June, p. 5.

2. Chandler, J. S., and Holzer, H. P. "Preconditions for the Introduction of Computer-based Accounting Systems in Less Developed Countries," Management International Review, 1985, 85:2, pp. 53-60.

3. Datamation. Pushing the State-of-the-Art, 1985, October 1, pp. 68-84.

4. Garrison, Ray H., Managerial Accounting: Concepts for Planning, Control, and Decision Making, Plano, Texas: Business Publications, Inc., 1985, pp. 14-16.

5. Golland, Marvin L., and Fray, Nancy B. "A Period of Adjustment," Management Focus, 30:3, 1983, May-June, pp. 16-18.

6. Harmon, Paul, and King, David. Expert Systems: Artificial Intelligence in Business, New York: John Wiley \& Sons, Inc., 1985, pp. 5.

7. Hughes, Cary T., Adequacy of Computer Training for the Non-Data Processing Manager, Journal of Systems Management, 37:1, 1986, January, pp. 15-17.

8. Koehler, Gary J., Artificial Intelligence: Getting Machines to Think. The Government Micro User's Catalog, 1986, Winter, pp. 36-43.

9. Kowalski, Robert., AI and Software Engineering, Datamation, 1984, November 1, pp. 99-102.

10. Management Accounting, Management Accounting's PC Package Review, 67:1, 1986, January, pp. 57-73.

11. McLeod, Raymond, Jr., Management Information Systems, Chicago: Science Research Associates, Inc., 1983, p. 476-478.

12. Ross, Steven S., Artificial Intelligence, Business Week's Guide to Careers, 1986, March, pp. 22-27.

13. Shannon, Terry C., AI at Work, Digital Review, 1986, May, pp. 62-69.

14. Stewart, Rodney D. and Stewart, Ann L., Cost Estimating With Microcomputers, New York: McGraw-Hill Book Company, 1986, p. 3.

15. Van Horn, Mike, Understanding Expert Systems, New York: Bantam Books, 1986.

16. Wesserman, Anthony I., et al. Building Reliable Interactive Information Systems, IEEE Transactions on Software Engineering, Vol. SE-12, No. 1, 1986, January, pp. 147-155. 